\section{Technical Authorship}

A SCHEME of instruction and examination in technical authorship, intended for those with engineering, technical or scientific training and experience, has been drawn up by the City and Guilds of London Institute Advisory Committee with the needs of the younger entrants in mind. The examinations will also be open to practising technical authors. The regulations and syllabuses are detailed in a pamphlet, "Technical Authorship", issued by the Institute (pp. 9. London: City and Guilds of London Institute, Gresham College, 1958. 9d.). A four-year part-time course of instruction is envisaged and the Intermediate examination of the Institute will be taken at the end of the second year and the Final examination at the end of the fourth year of the course.

\section{Queen Victoria Museum and Art Gallery, Launceston}

The report for 1956-57 of this progressive Museum and Art Gallery records that the renovation programme has been continued. The main projects have been the complete reconstruction of the china room, the construction of new cases in the vertebrate gallery, improvements in the lecture room and additional storage accommodation. In association with the University of Tasmania, an expedition to examine the rock markings in the Blue Tier district was undertaken. It is suggested that these are aboriginal in origin. Also in association with the local field club, an exhibition of native plants was arranged and maintained for about three months. The engagement of a temporary assistant in the geological department produced considerable development in this sphere, and many improvements were effected.

The Records of the Queen Victoria Museum, New Series No. 9, includes an important paper on the Van Diemen's Land Company 1825-1842 by $\mathrm{Mr}$. A. L. Meston (pp. 62. 1958. Launceston, Tasmania : Queen Victoria Museum). From a study of the wool trade in Britain and the increasing inadequacy of the supply of fine wool the work proceeds to the chartering of the Van Diemen's Land Company in 1825. Its grant was for districts outside the settled areas and its power confined to producing fine wool. The colonists, however, were suspicious of absentee monopolists, and the regions of land granted were quite unsuited to raising fine-woolled sheep. Stock losses were heavy from weather, wolves and aborigines. Finally, the management were unable to overcome the natural and official obstacles, and the Company closed in $\mathbf{1 8 4 2}$. The paper forms an important side-issue of the early history of the wool trade in England.

\section{Stable Graticules}

Messrs. Graticules, LTd., have recently introduced a new graticule process which they term 'maXta' (for maximum stability). It has the advantage that the graticule is composed solely of a noble metal on glass; there is no gelatine or other support material. The image is firmly bonded to the glass and is extremely resistant to abrasion, obviating the necessity for a cover glass. This is an important consideration, since breakdown in graticules is often associated with the cover-glass cement. Further, the absence of gelatine means that there is no suitable substrate for fungal attack - an advantage in tropical conditions. The method is based upon work com- menced by the late Julius Rheinberg. It is essentially a photographic process and is most suitable for lines on a transparent ground rather than the reverse. The technique can be applied to most of the available glasses. Three types are made having varying optical qualities. These variations are associated with the adhesion rather than with the image quality, which in each case is very good. These graticules were developed in the course of work carried out at the British Scientific Instrument Research Association, Chislehurst, Kent.

\section{Germination of Oil-Palm Seed}

THE results of an interesting investigation of the factors controlling seed germination in the West African oil palm, Elaeis guineensis (Jacq.) have been given by G. Hussey (Annals of Botany, N.S., 22, $259 ; 1958)$. It is recorded that under natural conditions in West Africa, at the average ground temperature of $25-30^{\circ}$ C., oil-palm seed germinates sporadically over a period of years, but with continuous heat treatment $\left(38-40^{\circ}\right.$ C.) 50 per cent germination of either nuts or extracted kernels occurs within a few months. The kernel comprises a small cylindrical embryo embedded in a mass of oily endosperm which in turn is surrounded by a thick testa. At germination the testa and layer of endosperm covering the distal part of the embryo are forced out as a disk-like operculum which is already demarcated in the ungerminated kernel by a circular abscission zone in the endosperm cells. The excised embryo is non-dormant and at $30^{\circ} \mathrm{C}$. starts to elongate within $24 \mathrm{hr}$., either on moist filter paper or while still in contact with the endosperm. At $30^{\circ} \mathrm{C}$. removal of the operculum is followed by $a$ sluggish emergence of the embryo in air ; emergence at the normal rate occurs in pure oxygen, or in air if a long period at high temperature precedes deoperculation. Fresh intact kernels remain ungerminated for at least six months at $30^{\circ} \mathrm{C}$, either in air or in pure oxygen. At high temperature $\left(40^{\circ} \mathrm{C}\right.$.) intact kernels germinate faster in pure oxygen than in air ; at $30^{\circ} \mathrm{C}$. the same applies only after previous treatment at high temperature. This accelerating effect of oxygen is shown to be dependent upon the progress of slow processes stimulated by high temperature. It is postulated that germination of oil-palm seed is dependent upon a minimal threshold concentration of oxygen in the embryo and that during dormancy this minimal level progressively decreases at a rate depending on the temperature.

\section{Harkness Fellowships of the Commonwealth Fund}

THE awards which have borne the title of Commonwealth Fund Fellowships since 1925 are being offered for 1959 under the title of Harkness Fellowships of the Commonwealth Fund. The Fund is an American philanthropic foundation endowed by the late Mrs. S. V. Harkness and the late Mr. and Mrs. E. S. Harkness, for promoting international understanding by providing opportunities for education and travel in the United States. Fellowships tenable in the United States are offered in separate series in the United Kingdom, in Australia and New Zealand and in Western Europe. Thirty Fellowships are offered in the United Kingdom for 1959 to men or women who have not previously worked for more than a few months in the United States, and who are graduates or have experience in government service, the professions, the creative arts, journalism, branches of business or industry. Forms of applica- 